\title{
ABORIGINES, ELKIN AND THE GUIDED PROJECTILES PROJECT
}

\author{
Geoffrey Gray
}

The Chifley Labor government announced on 19 November 1946 that they had agreed to the British government's request that a guided projectile range be established in the 'largely' uninhabited spaces of Central Australia: 'except for a few pastoral leases at the firing point end in South Australia, the Central Australian Aboriginal Reserves and a few more pastoral leases adjacent to the Ninety Mile Beach in Western Australia, the area of the range and that which it is proposed to reserve for eventual extensions, is largely uninhabited'. ${ }^{1}$ There was some concern over the effect this development would have on Aborigines living in the area and the encroachment on the nearby Central Australian Aboriginal Reserve.

The Guided Projectiles Project Committee was formed originally to oversee the testing arrangements of the rocket range but it had no interest in the welfare of Aborigines living in the testing area. A.P.Elkin was asked to join the Australian Guided Projectiles Committee to, in the words of his biographer, 'allay public fears that the Aborigines would be at risk'. ${ }^{2}$ Elkin was aware that his appointment could be misrepresented and to avoid any accusations of collusion he suggested that the government invite the Australian National Research Council (ANRC) to nominate an anthropological expert. Naturally he would be nominated. ${ }^{3}$

Elkin used his influence and authority to advocate and support the government's decision despite the apparent dangers inherent to Aboriginal welfare if a rocket range was established within the boundaries of the Central Australian Aboriginal Reserve. In return for his support Elkin required that the government provide adequate safeguards for Aborigines living within the area of the rocket range.There is enough evidence to suggest that Elkin believed that it was best to leave Aborigines in their 'traditional' areas and that they could find work in the pastoral industry. 4 Further there is reference to the protection of sacred

Geoffrey Gray has recently completed his M.A. Thesis at Monash University on A.P.Elkin and his authority with government in the 1940s. His current interest is anthropology and assimilation.

1 J.J.Dedman, Minister for Defence. Statement to the House of Representatives, 22 November 1946.

2 Wise 1985:199.

3 Ibìd.

4 Berndt and Berndt 1987:32. Elkin asked the Berndts to 'study the social and psychological reasons' if Aborigines are 'not forthcoming' and to advise Vesteys on 'ways of improving the conditions and attitudes'. The aim, and this appears fundamental to all, except the Berndts, was to build up 'a contented [A]boriginal community in the regions in which they are accustomed, and around the Pastoral Industry which they like': Implicit in Elkin's suggestion is that Aborigines are of value only within their locality and should not be encouraged to leave their areas and they were to remain an underclass providing cheap labour for the pastoral industry. 
sites in the recommendations of the GPP Committee..$^{5}$ Elkin was acceptable to government because he was reliable in the sense that his actions and purpose in matters relating to Aboriginal welfare were consistent and he was reluctant to criticise the government publicly. The Guided Projectiles Project provides a demonstration of his reliability. It illustrates firstly, the way in which he used his authority and influence, and how the government, in particular, relied upon this, and secondly, the problems of contact and change and the relationship between anthropology and the interests of the 'colonisers'.

There was no question for Elkin that Australia needed to have the guided projectiles experiments in Australia; it was a 'duty to Empire'. Both sides of the Parliament accepted it. Initially the problem was not with adequate safeguards for Aborigines, rather it was whether there were adequate safeguards against subversion, intrusion and espionage by Communists and fellow travellers.

The Minister for Defence, J.J.Dedman, asserted that the area was largely uninhabited and that the risk to Aborigines was negligible: 'the probability of a missile falling on them would be extremely remote. ${ }^{6}$ He gave an undertaking, after opposition gathered public support, that the government would do 'everything possible to safeguard the [A]borigines from contact, or encroachment on any area of special significance to them'?

These assurances and others given by politicians were not readily accepted by the various groups concerned with Aboriginal welfare and opposed to the creation of the project. $^{8}$

Opposition to the Project was led by Mrs Maurice Blackburn, an independent MHR, Dr Charles Duguid, an Adelaide surgeon and a leader of the Presbyterian Church, and Dr Donald Thomson. On 16 December 1946 Mrs Blackburn put on Notice the following motion:

That in the opinion of this House:

1. the proposal to establish a rocket bomb testing range in Central Australia is an act of injustice to a weaker people who have no voice in ordering their own lives; it is a betrayal of our responsibility to guard the human rights of those who cannot defend themselves; and a violation of the various charters that have sought to bring world peace; and

2. such action is against the interests of the people of the Commonwealth. ${ }^{9}$

Public criticism led the government to co-opt new members onto the Guided Projectiles Project Committee. It was hoped, wrote F.G.Shedden, Secretary, Department of Defence, to the Prime Minister, Ben Chifley, the new constitution of the Committee would bring about a satisfactory solution to the question of safeguards for Aborigines 'before the House meets and an adequate answer to any further criticism'. ${ }^{10}$

The new members were Elkin, F.J.Moy ${ }^{1}$ (Director of Native Affairs, NT),

5

6 Hansard, 22 November 1946, statement to the House of Representatives.

7 Ibid.

8 See Wilson 1980 for the coalition of groups opposed to the GPP.

9 Hansard, 6 March 1947:435.

10

11. Shedden to Chifley, 31 January 1947, quoted in Japanangka and Nathan 1983.

Moy and Elkin shared a dislike of Donald Thomson's views about 'native' welfare; they concurred in their views on assimilation. Moy wrote to Elkin in 1947 that 'the matter of preserving tribal institutions and customs within the framework of our society...savours too much of keeping a live museum and there are certain of our friends who dread the 
A.O.Neville ${ }^{12}$ (retired Chief Protector of Aborigines, and representative of the Western Australian government), and W.R.Penhall (Secretary of the Aborigines Protection Board, SA). The selection of these people ensured the acceptance of the project. Duguid and Thomson were appointed as non-voting consultants. ${ }^{13}$ Wise claims Elkin was prepared to provide support for the Project in return for the following safeguards:

a patrol officer to regulate contacts, protection of sacred sites, no transfer of

Aborigines from place to place, no Aborigines to be used for labour, and airstrips to be used rather than roads. ${ }^{14}$

This was agreed upon and Native Patrol Officer Walter MacDougall was appointed. ${ }^{15}$ Elkin then made no further protest to the government. ${ }^{16}$ Both Duguid and Thomson, who had been appointed as consultants to the Committee in an attempt to weaken their protest and to compromise their arguments, 'realised that reason and argument would have no effect against closed minds (of the Committee). The military mind was made up long ago'.17 Duguid clearly placed Elkin with the military's 'closed minds'.

Two months later, on 31 March 1947, in an address delivered at the Melbourne Town Hall, Charles Duguid accused Elkin of changing position; detailing the composition of the Committee and the members co-opted specifically to examine the problem of contact with the Aborigines he said of Elkin that he was in close touch with the

thought of the Australian [A]boriginal becoming a normal citizen - one in particular would miss [Thomson's] occasional ill-informed articles in the Melboume Herald:' (Moy to Elkin, 17 July 1947, AA:CRS, item 52/570).

12 Elkin wrote the foreword to Neville's Australia's coloured minority, 1947. Neville recognised Elkin's authority, and both shared the belief that the Empire's defence against extemal threats was important.

13 Composition of the Australian Guided Projectiles Committee:

Major-General L.E.Beavis, Chairman (representing the Department of Defence),

Commander N.K.Coldser (representing the Department of the RAN),

Wing-Commander A.G.Pither (representing the RAAF),

N.K.S.Brodribb (Department of Munitions),

F.W.G.White (Council for Scientific and Industrial Research).

The following appointments were made in response to the public outcry over Aboriginal welfare and safety:

F.H.Moy (Director, Department of Native Affairs, NT),

W.R.Penhall (Secretary of the Aborigines Protection Board, SA),

A.O.Neville (representing the WA government),

A.P.Elkin (ANRC),

L.F.Loder (Director-General, Department of Housing),

Lieutant-General J.F.Evetts (representing the British Long Range Weapons

Organisation).

Two consultants were appointed:

Di Charles Duguid,

Dr Donald Thomson.

Wise 1985:200.

15 Charles Duguid maintained that the only so-called 'achievement' of twelve months sustained protest was the appointment of McDougall; McDougall had earned the respect of the Aboriginal people whilst an employee at Emabella Mission. It was his task to provide care and protection of the Reserve's Aborigines and also to issue warnings regarding the firing of missiles.

16 Such behaviour by Elkin typifies of the way he worked.

17 Duguid 1947:12. 
Federal Government through the Australian National Research Council...[and] admits he has changed his views regarding the effect of sudden contacts between white people and Aborigines since the Rocket Range was first discussed. He further admits he would not by choice run a Rocket Range through the Aborigines Reserve with a view to benefiting the Aborigines.

Duguid asserted that a 'recent trip' 18 by Elkin through the Northern Territory had provided him with information that had convinced him that Army contact had not hurt the Aborigines. ${ }^{19}$ It was not an argument that held weight for Duguid; he referred to other 'authorities', such as Pastor Albrecht of Hermannsburg Mission in Central Australia, 'who during the war saw the immediate effects of the Army on the natives, and is now seeing the late effects, is definite that no experience has ever done the natives more harm'; and Dr Donald Thomson'who,' during part of the war, was in charge of a native patrol from the Gulf of Carpentaria to Broome on the coast, and inland throughout the whole of the Northem Territory, is emphatic about the serious damage suffered by the Aborigines because of the military occupation of the Territory ... No one is more competent to judge than he'.20

Elkin, who saw a solution in the provision of 'adequate safeguards' as he did not believe anything could halt the project, wrote in February 1947 to the Guided Projectiles Project Committee disparaging Duguid and Thomson:

neither of these gentlemen suggested any ways in which the Committee might fulfil its purpose, namely to safeguard the Aborigines while carrying out the project, their attitude being a negative one'. ${ }^{21}$

The recommendations 22 of the Committee, announced in Parliament in May, essentially supported Elkin's proposals, and did not directly address the opposition of Duguid and Thomson. It was acknowledged that the project would cause considerable disruption to Aboriginal life but the Committee stated, in their first recommendation, that

De-tribalization of the Aborigine is inevitable, and provided the contacts brought about by the construction and use of the range are controlled and of a wholesome nature, their only effect would be the putting forward of the clock regarding de-tribalization by possibly a generation. 23

This de-tribalization could be further controlled by the appointment of patrol officers. It was argued that any acceleration of the de-tribalization which is now taking place, or the interference with the habits of the Aborigines and areas of special significance to them, which have existed from time immemorial', can be controlled by the appointment of patrol

18 This is somewhat of an exaggeration by Duguid: Elkin's 'recent trip' was in August 1946 when he visited Darwin and parts of Amhem Land for the first time.

19 Elkin argued earlier that such contact would be detrimental to the Aborigines but altered this view when it was evident that Aborigines had 'prospered'. He thought diet and the regime imposed by the Army, as well as fair remuneration were the main factors. (Elkin Papers, 55/1/12/6, Archives, Sydney University).

Duguid 1947:12-14,

$21^{-}$Elkin to the Guided Projectiles Project Committee, February 1947, quoted in Wise 1985.

22 Japanangka and Nathan 1983:55 state that the recommendations that were:made public excluded parts which not did allay the concerns of those groups and individuals opposed to the construction of the rocket range and its effects on Aborigines in the area, nor did they make public how extensive the testing program was going to be. $:$; .

Hansard, 1 May 1947:1832. 


\section{ABORIGINES, ELKIN AND THE GUIDED PROJECTILES PROJECT}

officers. It continued that

interference with the aborigine by reason of:

i) mass transfer of aborigines from the Central Reserves;

ii) employment of aborigines for labour;

iii) construction of roads within the Central Reserves;

iv) undue publicity of the use of the range, causing the movement of the aborigines towards it, can be discounted entirely, as none of these courses of action is contemplated.

Publicly the Committee concluded that the welfare of the Aborigines would not be jeopardised although it was well understood that the construction of the rocket range would cause considerable disruption. Aborigines were expendable for the good of the Empire.

The recommendations of the Committee did not stop protest and criticism, but it moved the focus away from Aboriginal welfare so that protest could be presented as Communist inspired. As early as November 1946, S.R.Rowell, Lieutentant-General Vice Chief of the General Staff, wrote 'that the communist party was inciting and using the protest to their own ends' and that public opposition should be viewed with this in mind. 24 The Melbourne Argus of 13 May 1947 wrote that the opponents of the project 'form a motley crew' and behind the 'pacifists, day dreamers and humanitarians' it was not 'difficult to perceive the directing hands of the Communists'.

Dedman claimed that much of the criticism was based on misunderstanding, firstly of what the project meant, and secondly of its effects on the welfare of Aborigines. Such a decision, as that reached by the Committee, was not made without a great deal of discussion and a 'complete examination' of the possible effects 'such a project would have on our aboriginal peoples in the areas that were most suitable for the purpose'. ${ }^{25}$

Elkin was firmly identified with government. In a statement to missions and other concerned humanitarian groups made after the Committee had made its recommendations, he wrote that there was no point protesting because the project had been decided by 'Empire' leaders and his task had been to protect Aboriginal interests, to see that the Aborigines were not being interfered with in any way detrimental to their welfare. It was pointless wasting energy in 'futile protests or abstract arguments'. ${ }^{26}$ This did not convince the missions; as a body they stood in opposition to Elkin. Elkin's response was to resign from the Australian Board of Missions (ABM) and the National Missionary Council (NMC).

He wrote a letter of resignation in July 1947 to the NMC in which he complained of being put in a serious state of duplicity.

I have issued a statement along one line and now the Council of which I am a member has issued a statement which does not agree with mine and to some extent contradicts it. 27

In the same month he wrote to the $A B M$ strongly objecting to the suggestion that he had been constrained as a member of the Committee and thus unable to express his 'true feelings'. He wrote:

May I say I strongly object to the insinuation implied. It is the first time it

24 Rowell to Secretary of the Army, 11 November 1946, quoted in Japanangka and Nathan 1983.

25 Hansard, 1 May 1947:1829.

26 Elkin 1947.

27 Elkin to National Missionary Council, July 1947. (Elkin Papers, 55/1/12/6, Archives, Sydney University). 
has been suggested that I am a coward with regard to my fundamental views. 28

Some fifteen years later Elkin wrote about his role and again rejected the argument that he was constrained by the interests of the government. He claimed he was asked to ensure the well-being of the Aborigines was being looked after; he was

given to understand that if, after the conference (sic), I cared to make a statement on this aspect of the matter, the Government would welcome my action, being sure such a statement would be received with confidence by all the humanitarian and missionary bodies who were perturbed. ${ }^{29}$.

Elkin believed the government had confidence in him, and that they could rely on his support, although it is difficult to judge whether his support would be unconditional. Not all humanitarian and mission bodies accepted his statement that Aborigines living in the test area would be adequately safeguarded despite his assertion that his statement 'reassured all except a few individuals who did not want to be reassured'. ${ }^{30} \mathrm{He}$ wanted to leave the reader in no doubt of his correctness in supporting the project and any opposition was again dismissed as having the temerity of not accepting his authority.

Opposition continued from his old adversary Donald Thomson, who was unwilling to compromise his views which ran counter to the government's position. Thomson and Elkin had previously positioned themselves differently in regard to Aboriginal policy and representation. Those opposing representations were highlighted over the Guided Projectiles Project. Thomson believed 'the roads, scientific experiments, detonations and patrols would be highly disruptive and destructive of these peoples' way of life...so the range should be established elsewhere' ${ }^{31}$ Elkin was adept at maintaining his links with government. He was pragmatic and willing to compromise his beliefs and principles; it could be argued that Elkin recognised that outright opposition would be unsuccessful. He recognised the inevitability of contact and its effects, but he nevertheless thought contact could be controlled. The experiences of the Army during the war provided evidence that contact need not be disastrous. Elkin was not there as an apologist for the government; ${ }^{32}$ it is however in the light of the above discussion difficult to get away from the fact that he placed the government's priorities above those of principle and belief.

Elkin's reversal was highlighted by his continued assertions, both publicly and in his correspondence, of the deleterious effects of contact. As late as 1948 Elkin was expressing concern over the effects of contact, and the consequent depopulation. Aboriginal health and reproductive power were undermined by the effects of contact. He added that

the fact that their country is invaded, their ritual life broken down and that they are reduced to parasitism [on Europeans]...In the middle of this is the refusal of women to have children to face this parasitic future and in some cases their inability to do so because of disease contracted directly or indirectly from white men. 33

Elkin to Bishop Cranswick, Australian Missionary Board, July 1947. (Elkin Papers, 55/1/12/6, Archives, Sydney University).

Ibid.

Peterson 1983:13.

Ibid.

Conference of Commonwealth and State Aboriginal Welfare Authorities, 3 February 
Duguid and other humanitarian leaders were confused, and disappointed by Elkin's reversal and his support for the government. They had expected support from Elkin. Bishop Cranswick, for example, believed his own opposition to the Project was based on sound anthropological teaching as propounded by Elkin who had argued that 'too rapid contact with white culture and too sudden break with the 'past' must be prevented' ${ }^{34}$ Cranswick could not, therefore, accept Elkin's support of the government other than to believe he was a 'tool of the government'.35

Elkin's theory that abrupt change and depopulation were linked was challenged by the success the Army had with Aborigines which was characterised by good diet, regular remuneration and dignity. Elkin believed that if these three conditions could be maintained 'it was probable the pace of change towards an equal place in white society could be vastly quickened'. ${ }^{36}$ But this does not get him off Cranswick's hook. It was not a position he argued over the GPP as his main focus was on the inevitability of the rocket range and the fact it was an 'Empire' matter.

His changed position was not reflected in his address to the Conference of Commonwealth and State Aboriginal Welfare Authorities in 1948 although he did write in 1944 , that Aborigines 'must be prepared for life in contact with white society and culture' 37 and it was of little significance if it occurred earlier rather than later. Such contact was inevitable and the construction of the rocket range, on balance, took precedence over Aboriginal welfare given that on this view their welfare was not seriously threatened.

In hindsight it is clear that each safeguard Elkin had insisted upon was vulnerable. The two patrol officers were to inform any Aborigines likely to be near the part of the range where rockets were likely to fall. This was complicated by the safeguard that Aborigines were not to be forcibly removed or transferred. The regulation of contact between Aborigines and Europeans was difficult if not impossible. Elkin had no doubts about the effectiveness of the safeguards and the protection afforded to Aborigines by those safeguards. He wrote in 1947 that,

Those of us who know the Aborigines in the central areas of Australia and their way of life know that it can be done. ${ }^{38}$

Nevertheless, his support was consistent with his actions in the past such as his efforts to stop publication of the Berndt's report and the removal of their findings from public forum s. ${ }^{39}$ His disappointed supporters, the ABM, the NMC, Duguid and others, were correct to claim that he altered his position because of the contingencies and

1948, 55/1/12/6. (Elkin Papers, 55/1/12/6, Archives, Sydney University).

Elkin 1944:45.

Wise 1985:200.

Ibid.:168.

Elkin 1944:45.

Elkin 1947:103.

See my MA thesis, pp.46-48. Elkin argued to the Berndts that the report would have more influence on the AIA and on government opinion 'if it were treated privately'; he notated on a paper which Ronald Berndt delivered to the Anthropological Society of New South Wales in 1948 that if 'anyone asks what stations are these, say - the [?Anthropology] Department doesn't want this to be a political matter while the [Northern Territory Pastoral] Award is in the offing' (R.M.and C.H.Berndt 1987:271). Almost thirty years later Elkin put forward a similar argument; he wrote that 'Mr Bingle would have maintained that a report on work in 1944-46 was for the eyes and use of the Firm alone' (Elkin to R.M.and C.H.Berndt, 30 July 1946). 
requirements of government. He did not challenge the government, and the examples I have referred to substantiate this argument. Over the project his authority and influence were used to support the government's decision. Speeding up the 'inevitable detribalization' of the 1800 Aborigines estimated to be in the area was of small matter in contrast to the defence of the Empire.

In 1962 Elkin was still defending his decision; it seems that he had not reflected on the events after 1947 although it was evident that the government had clearly ignored safeguards which interfered with the continued testing of rockets and later, from 1953, atomic bombs. ${ }^{40}$ The future revealed that the Weapons Research Establishment, the successor to the Guided Projectiles Project, accorded Aborigines low priority and placed the 'affairs of the British Commonwealth' above 'those of a handful of natives'. ${ }^{41}$

Elkin had worked behind the scenes from the mid-1930s to bring about change to Aboriginal affairs because he believed public protest was futile and bound to fail. He did not challenge the legitimacy of 'colonial' rule, he wanted only to ameliorate the conditions of Aborigines arguing that their future lay in their eventual assimilation and incorporation into mainstream 'white' society. 42 As an authority on Aborigines he saw himself not only as a mediator between government and Aborigines but as a guardian of Aboriginal welfare although he had no mandate to assume such a role.

In a letter to Gillespie Douglas, president of the Victorian Aborigines' Uplift Society, he wrote in January 1947 that he devoted 'much energy to exposing and attempting to rectify injustices and ill-considered plans regarding Aborigines' ${ }^{43}$ This demonstrates, again, Elkin's sense of his own correctness, and his belief that he alone knew what was best for Aborigines. He did not reflect on his actions and appeared to listen to others only if it fitted in with his ideas and plans.

In both his correspondence and published papers Elkin often inflated his importance. He did this in part to inform his readership that he was a man of substance, who was responsible for the improvement in Aboriginal welfare and policy. It is true to say, as Rowley claimed, 44 that assimilation was at the time an enlightened policy based on the assumption that there 'are no proven inherent differences in capacity between the races of mankind', although its practice probably differed little from previous policies. Assimilation, however, denied the existence and validity of an Aboriginal culture in settled Australia. 45

Part of the explanation of Elkin's success as an authority was that governments could rely on him to be discreet, to work within the parameters of government policy and values,

40

42

43

44

45

Wilson 1980.

James McClelland, Royal Commission, 1985:305.

Elkin 1944:90.

Elkin to Douglas, January 1947, cited in Wise 1985:174.

Rowley 1972.

Read 1982:17 writes that 'though the lifestyle, attitudes, behaviour and beliefs of the part-Aborigines may not have been quite the same as those of full descent, their culture offered a comparatively unified and fulfilling lifeway. It compromised many elements not usefully disentangled, which included a strong measure of traditional attitudes and customs, some European values, a reaction to European exclusion, a pride in Aboriginal identity...In Yass in 1930, Aborigines lived within a changed but sustaining culture...Aboriginal culture in Yass was changing no faster than European. Aborigines neither wished to become like white, nor were they quickly becoming like whites...Aboriginal resistance to the cultural demands of whites has run very deep'. 


\section{ABORIGINES, ELKIN AND THE GUIDED PROJECTILES PROJECT}

and most importantly they could rely on him not to challenge the existing order. Thus Elkin could be appointed to various government committees, such as the Guided Projectiles Project Committee, and provide support for government decisions; sometimes, as with the Guided Projectiles Project, he would collude with government.

Yet I think Elkin, after 1938, was always compromised because of his association, and public identification, with the formulation of policy and its implementation. This was particularly so in New South Wales where it was compounded by his membership, from 1941, of the Aborigines' Welfare Board. ${ }^{46}$ His appointment to the Welfare Board closed the gap between anthropologist and administrator; earlier through his representation on humanitarian associations such as the Association for the Protection of Native Races and various mission boards, such as the Australian Board of Missions, he had fostered the importance of anthropology as a tool of change; now all these agencies were together, indivisible in engineering change for Aborigines. It was the nexus of anthropology, government and mission: Elkin oversaw them all.

His reluctance to publicly criticise govemment, his control of research money and areas of research by his chairmanship of the ANRC and the Department of Anthropology, and his membership of the AWB ensured the maintenance and continuance of his authority and influence. In turn he was supported by government agencies, particularly by senior public servants such as J.A.Carrodus, secretary of the Department of the Interior, and W.C.Wurth of the NSW Public Service Board.

In a letter to the Treasurer and Prime Minister, Ben Chifley, Elkin requested more funds for the Anthropology Department which was supported by the then Secretary of the Department of the Interior, McLaren, who observed that Elkin had 'always been regarded as an unofficial consultant to the Department in matters effecting [A]boriginal welfare in the Nothern Territory' 47 This is illustrative of the continued relationship Elkin had with government authorities. For government, and its administrators, his greatest value was in the words of McLaren's predecessor, J.A. Carrodus, that he was 'not a purely academic anthropologist but was very realistic in his outlook', ${ }^{48}$

\section{Acknowledgments:}

I wish to thank Andrew Markus and Bain Attwood.

\section{BIBLIOGRAPHY}

Berndt, R.M. and C.H.Bendt. End of an era: Aboriginal labour in the Northern Territory. Canberra, 1987.

Duguid, Charles. The rocket range, Aborigines and the war. Melbourne, 1947.

Elkin, A.P. Citizenship for the Aborigines: a national Aboriginal policy. Sydney, 1944. - 'Introduction', in A.O. Neville, Australia's coloured minority: its place in the community, pp.11-19. Sydney, 1947.

'Australian Aboriginal and white relations: a personal record', Royal Australian Historical Society Journal 48 (3), 1962:208-30.

46 At the end of his service, and the end of the AWB, in 1967, Elkin congratulated the Board and presumably himself on the good they had achieved.

47 McLaren to Driver, 2 September 1949, AA: CRS F1 1946/767.

48 Carrodus to Driver, 15 July 1946, AA: CRS F1 1946/767. 


\section{ABORIGINAL HISTORY 1991 15:2}

Japanangka, Dick and Pan Nathan. Settle down country. Melbourne, 1983.

Markus, Andrew. Governing savages. Sydney, 1990.

Peterson, Nicolas. Donald Thomson in Arnhem Land. Melbourne, 1983.

Read, Peter. 'A double headed coin: protection and assimilation in Yass 1900-1960', in B.Gammage and A.Markus eds., All that dirt: Aborigines 1938: an Australia 1938 monograph, pp.9-28. Canberra, 1982.

Rowley, C.D. The destruction of Aboriginal society. Ringwood, 1972.

Wilson, Paul. Rockets and Aborigines, August 1945-August 1947. B.A. Hons Thesis, LaTrobe University, 1980.

Wise, Tigger. The self-made anthropologist: a life of A.P.Elkin. Sydney, 1985. 